\title{
Determining patterns of the geomechanical factors influence on the fastening system loading in the preparatory mine workings
}

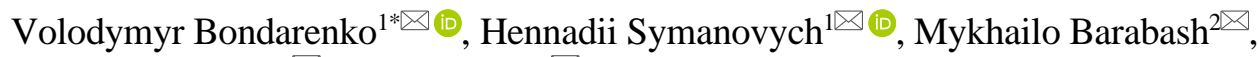 \\ Oleksandr Husiev $^{3 \otimes}$, Ildar Salieiev ${ }^{4 \bowtie}$ \\ ${ }^{1}$ Dnipro University of Technology, Dnipro, 49005, Ukraine \\ ${ }^{2}$ LLC "DTEK Energy”, Kyiv, O1032, Ukraine \\ ${ }^{3}$ MM "Dniprovske", PJSC "DTEK Pavlohradvuhillia", Pavlohrad, 51400, Ukraine \\ ${ }^{4}$ PJSC "Donetsksteel" - Iron and Steel Works", Kyiv, 01133, Ukraine \\ *Corresponding author: e-mail v_domna@yahoo.com, tel. +380562471472
}

\begin{abstract}
Purpose. Substantiation of calculating the rational parameters of reaction and yielding property of the fastening system in the preparatory mine workings.

Methods. The stress-strain state analysis of the "massif - support" system and the normative documents on support calculation of the preparatory mine workings to determine the patterns of link between the fastening system parameters and the main geomechanical factors.
\end{abstract}

Findings. The patterns of geomechanical factors influence on the parameters of reaction and yielding property of the fastening system have been determined, as well as the analytical expressions for their calculation have been obtained.

Originality. Correlation-dispersion analysis of the optimization data has revealed a stable exponential relation between the parameters of reaction and the yielding property of support with an index $H / R$, regardless of the coal-bearing massif structure.

Practical implications. Calculation of the deformation-strength characteristic of the fastening system has been developed depending on the mining and geological conditions of maintaining the preparatory mine working.

Keywords: preparatory mine working, support, reaction and yielding property of support, characteristic, optimization, calculation

\section{Introduction}

Modern optimization methods are constantly being improved in the direction of accounting all the peculiarities of the support interaction with the rock massif, which encloses mine working [1]-[5]. In accordance with the ultimate goal of research - ensuring the mine working stability by costeffective technologies - determining the optimization parameters of the "massif - support" system elements interaction, is an urgent task [6]-[11].

Assessing the degree of adequacy and accuracy of the developed methodology for optimizing the interaction modes of the support and the surrounding rock massif [12]-[14] has revealed the positive results and the possibility of substantiating the next stage of research: searching for the patterns of link between the optimal reaction $P_{A}$ coordinates and the yielding property $u_{A}$ of the fastening system, depending on the index $H / R$ (where $H$-is the depth of mining, $R$ - is the average calculated compressive resistance of rocks) and the rocks structure of coal-overlaying formation in accordance with its division into three generalized groups [15], [16].

The coal-bearing stratum structure in the Western Donbas conditions is formed by a limited number of rock lithotypes (sandstone, siltstone, argillite, coal) of the immediate and main roof [17]-[19], which, as a rule, constantly occur in a sufficiently thick formation, consisting of uncontrolled collapse and hinged-block displacement zones [20]-[22]. With a total thickness of the mentioned zones of at least 12-15 extraction thicknesses of the seam, they are represented by rocks with different mechanical characteristics and typical for them planes of weakening, fracturing and water saturation [23]-[27].

It was proposed in the work [16], that "the division of mining and geological conditions should be performed according to the degree of their complexity with repeated use of extraction mine workings". Given that the noted work is the closest one to the ongoing research on optimizing the fastening system interaction modes of the reusable mine workings with the surrounding massif, a well-founded decision has been made to use the principle of grouping the mining and geological conditions in terms of the averaged structures of the adjacent coal-bearing stratum:

- I group - the most unfavourable conditions for maintaining the reusable extraction mine workings - is characterized by "... predominantly thin-bedded structure of the soft rocks $(f<1.5)$; the layers of argillite and siltstone with a 
thickness of more than $1.0 \mathrm{~m}$ with an average distance between the surfaces of weakening up to $1.0 \mathrm{~m}$; the layers of argillite and siltstone $(f=1.5-2.5)$ with medium thickness, which are periodically separated by water-flooded coal interlayers with a thickness of 0.1-0.3 m";

- II group - conditions of medium intensity of rock pressure manifestations - is characterized by "... thin-bedded and medium-bedded structure of water-free rocks with a hardness coefficient of argillite and siltstone $f=1.5-2.5$; medium-bedded and thick-bedded structure of water-flooded rocks $(f>1.5)$ at occurrence of sandstone with a thickness of up to $3.0 \mathrm{~m}$ ";

- III group - favourable conditions for the repeated use of extraction mine workings - is characterized by “... mediumbedded and thick-bedded structure of water-flooded rocks $(f>2.5)$ at occurrence of sandstone with a thickness of more than $3.0 \mathrm{~m}$; medium-bedded and thick-bedded structure of water-free rocks (f > 2.5)".

The separate series of computational experiments was performed according to these three groups of an adjacent massif structures, and, as a result, three families of graphs have been obtained which reflect the deformation-strength characteristic $q_{1}(u)$ of the weakened massif.

\section{Determining patterns of the link between the reaction and yielding property of support with geomechanical parameters}

For one and the same group with the typical rocks structure of the coal-overlaying formation (it is recorded to the roof height of $20 \mathrm{~m}$ ), each seven computational experiments have been conducted with different values of $H / R$. It should be reminded that in virtue of the elastic-plastic formulation for the stress-strain state (SSS) calculation problem, an arbitrary number of $H / R$ values can be obtained during one computational experiment. And the necessity to make several calculations of the geomechanical system SSS is conditioned by different thickness and deformation characteristics of the artificial rock layer [12]. Therefore, the technology of computations is as follows:

- the SSS is calculated for one model with fixed values of the thickness and deformation modulus of the artificial yieldable layer;

- the indications of functions $q_{1}(u)$ should be taken during the calculation at values of $H / R=10,20,30,40,50$, $60,70,80$ and $90 \mathrm{~m} / \mathrm{MPa}$;

- with a constant coal-overlaying formation structure, seven computational experiments are performed with the parameters of artificial yieldable layer, which provide the rock contour displacement from 300 to $1100 \mathrm{~mm}$ of the extraction mine working;

- for each fixed value of $H / R$, a graph is plotted for $q_{1}(u)$ function in seven points (coordinates $q_{j}, u_{j}, j=1,2, \ldots, 7$ ), which are determined during the above computational experiment;

- according to formula (1), considering (2) and (3), a graph of the function $q_{2}(u)$ is plotted [12]:

$q_{2} u=K_{d} B \gamma \frac{1-\alpha_{1}^{2}\left(1-\frac{K_{\text {inf }}}{100}\right)}{0.15+0.03 \alpha_{2}-0.18 \alpha_{1}} u$,

where:

$K_{d}$-dynamic factor, which takes into account the possible conventionally instantaneous displacements of massif around the extraction mine working; it is determined according to the recommendations [14];

$K_{i n f}$ - the coefficient of influence of the fastening system reaction on the constraint of the roof rocks lowering of the preparatory mine working, \%; it is determined by Table 1 .

$B$ - the width of mine working during driving;

$\gamma$-the weight-average unit specific gravity of rocks in the dome of natural equilibrium;

$\alpha_{1}$ and $\alpha_{2}$-parameters, setting the ratio between the lowering of the mine working roof in the areas: outside the zone of the stope works influence; in the zone of frontal bearing pressure of approaching longwall face; behind the stope face in the zone of stabilization of the rock pressure manifestations.

Table 1. The values of coefficient $K_{\text {inf }}$ of influence of the fastening system reaction, \%

\begin{tabular}{ccccccc}
\hline Weight-average & \multicolumn{6}{c}{ Fastening system reaction $P, \mathrm{kPa}$} \\
\cline { 2 - 7 } $\begin{array}{c}\text { compressive } \\
\text { resistance of the } \\
\text { dome rocks }\end{array}$ & 50 & 100 & 150 & 200 & 250 & 300 \\
$R_{\text {compr }}, \mathrm{MPa}$ & & & & & & \\
\hline 5 & 4.2 & 9.6 & 15.6 & 22.1 & 28.8 & 35.9 \\
10 & 3.0 & 6.8 & 11.1 & 15.6 & 20.4 & 25.4 \\
15 & 2.5 & 5.6 & 9.1 & 12.9 & 16.8 & 20.9 \\
20 & 2.1 & 4.8 & 7.8 & 11.0 & 14.4 & 18.0 \\
30 & 1.7 & 3.9 & 6.4 & 9.0 & 11.7 & 14.6 \\
40 & 1.5 & 3.4 & 5.5 & 7.8 & 10.2 & 12.7 \\
\hline
\end{tabular}

The parameters $\alpha_{1}$ and $\alpha_{2}$ have been obtained based on the calculated expressions [26], by transforming them for the solvable task of determining the function $q_{2}(u)$ :

$$
\begin{aligned}
& \alpha_{1}=\frac{1.5 R_{1}^{b} R_{3}^{r}+R_{3}^{b}}{3.0+2 m R_{3}^{b} R_{1}^{r}+R_{1}^{b}} ; \\
& \alpha_{2}=\frac{3.9 R_{2}^{b} R_{3}^{r}+R_{3}^{b}}{3.9+2 m R_{3}^{b} R_{2}^{r}+R_{2}^{b}},
\end{aligned}
$$

where:

$m$ - the extracted thickness of the coal seam;

$R_{1,2,3}^{r, b}$ - the calculated values of compressive resistance of roof rocks and bottom rocks of the coal seam in the appropriate areas: 1 - outside the zone of the stope works influence; 2 - in the zone of frontal bearing pressure; 3 -behind the longwall face; it is determined by the technique [28] with supplements from the work [16];

- the point $A$ of the graphs $q_{1}(u)$ and $q_{2}(u)$ intersection is determined with the corresponding coordinates $P_{A}$ and $u_{A}$;

- for each of the nine fixed values of $H / R$, the coordinates of the points $A$ are determined and graphs of functions $P_{A}(H / R)$ and $u_{A}(H / R)$ are plotted for visual presentation, as well as the data obtained are processed and the correlation equations for parameters $P_{A}, u_{A}$ with the $H / R$ index are derived using the correlation-dispersion analysis method;

- for the other two groups of the generalized structure of the coal-overlaying formation, the calculation procedure is repeated.

As a result, three dependences have been obtained of optimal loads $P_{A}(H / R)$ for each three generalized structures of the coal-overlaying formation, which reflect the Western Donbas mining and geological conditions (Fig. 1). The essence of the identified dependences is as follows. 


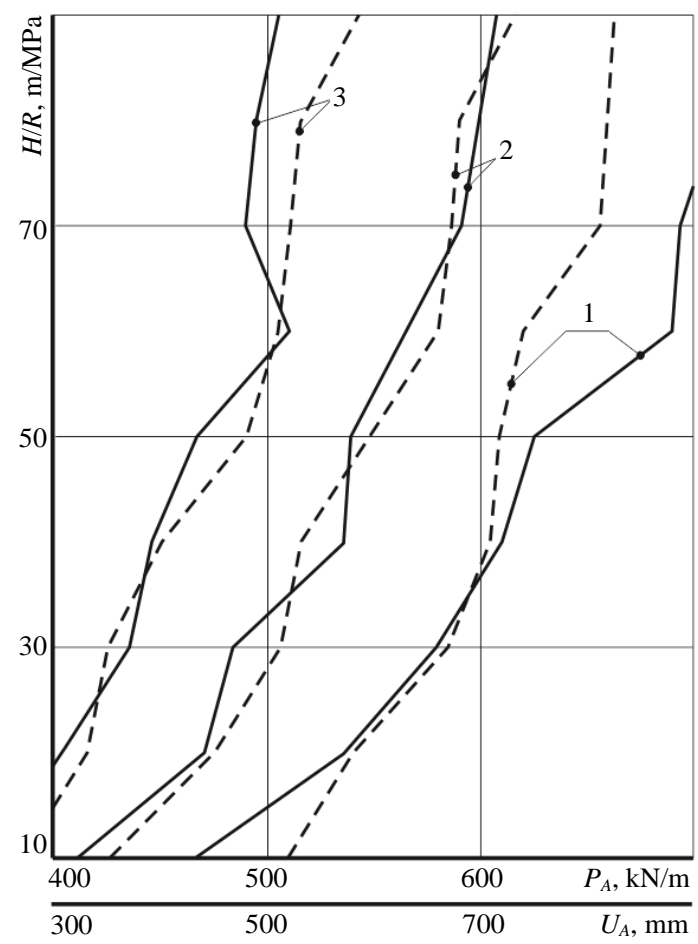

Figure 1. Patterns of link between the optimal parameters of reaction $P_{A}(-)$ and yielding property $u_{A}(---)$ of the fastening system depending on the $H / R$ index of mining and geological conditions and the structure group of coal-overlaying formation: 1 -I group; 2 - II group; 3 - III group

Firstly, the pattern is clearly observed of a decrease in the optimal load $P_{A}$ and yielding property $u_{A}$ of the fastening system with a decrease in the $H / R$ index, regardless of the rocks structure group of coal-overlaying formation. There is a very stable trend which fully corresponds to the existing concepts of geomechanics: the smaller the mine working location depth and the higher the enclosing massif hardness, the more restricted are the rock pressure manifestations. The differences of this result are in two positions.

On the one hand, the dependences $P_{A}(H / R)$ and $u_{A}(H / R)$ have been obtained for an area with the most intensive displacements of the coal-overlaying formation - after the stope face is driven; they are of significant practical importance in terms of making well-grounded technical decisions on the repeated use of extraction mine workings. On the other hand, a certain relation has been established between the optimal parameters of the fastening system operating mode and geomechanical factors, which was not previously known, especially for the zone of the stope works influence.

Secondly, based on the results of the geomechanical calculations complex, it becomes obvious the urgency of the task for optimizing the interaction modes between the massif and the support in terms of a stable decrease in the required strength parameters of the support, regardless of the complexity degree of conditions for maintaining reusable extraction mine workings. To elaborate on the above, the following facts are given according to the distinguished three groups of the rocks structure in the coal-overlaying formation.

For the I structure group of the coal-overlaying formation, an increase in the index $H / R$ from $10 \mathrm{~m} / \mathrm{MPa}$ (favourable conditions) to $90 \mathrm{~m} / \mathrm{MPa}$ (difficult conditions) leads to an increase in the optimal load value $P_{A}$ from 463 to
$718 \mathrm{kN} / \mathrm{m}$; therewith, the value of the optimal yielding property $u_{A}$ of the fastening system increases from 514 to $822 \mathrm{~mm}$. Therefore, an increase in the index $H / R$ of conditions for maintaining the extraction mine working by 9 times (an increase in the depth of mining with a decrease in the hardness of the enclosing rocks) causes a less intensive increase in the optimal load on the fastening system, equal to 1.55 times; the same can be said about the value of optimal yielding property: its increase in the considered range was 1.60 times.

For the II group structures, there are the following trends: an increase by 9 times in the index $H / R$ contributes to the growth of the minimum possible load $P_{A}$ on the fastening system by 1.49 times (from 407 to $606 \mathrm{kN} / \mathrm{m}$ ), and its optimal yielding property $u_{A}$ - by 2.11 times (from 348 to $734 \mathrm{~mm}$ ).

For medium-bedded and thick-bedded structures of the III group, the indicators are similar: by the value of optimal load - by 1.30 times; by the value of optimal yielding property - by 2.12 times.

Summarizing the above data, it should be pointed out that the influence of the index $H / R$ in thin-bedded structures is increased according to the value of the load and the influence is decreased according to the value of yielding property. In the medium-bedded and thick-bedded structures of the coalbearing massif, opposite trends of the index $H / R$ occur: a weakening in terms of the optimal load and an increase in the value of the optimal yielding property of the fastening system. At the same time, despite some differences in the patterns of the geomechanical index $H / R$ influence, it is necessary to note their significant disproportionality: a nine-fold index $H / R$ growth increases the optimal values of $P_{A}$ in the range of $1.30-1.55$ times and $u_{A}$ in the range of 1.60-2.12 times. This fact can be explained by the very principle of optimizing the force interaction between the fastening system and the surrounding rock massif: a search is made for such its operational parameters, at which the main rock pressure part is redistributed to the adjacent areas of massif, and the support takes up only that part of the load, which cannot be avoided in specific mining and geological conditions of maintaining the preparatory mine workings.

For ease of the determined patterns practical use (Fig. 1), a system of regression equations has been obtained, which set a link between the optimal parameters of the deformationstrength characteristic of the support with the geomechanical index $H / R$ and with the groups of generalized structures of the coal-bearing massif:

I Group $P_{A}=284 H / R^{0.21}, \mathrm{kN} / \mathrm{m}$;

$u_{A}=321 H / R^{0.21}, \mathrm{~mm}$.

II Group $P_{A}=270 H / R^{0.18}, \mathrm{kN} / \mathrm{m}$;

$u_{A}=172 H / R^{0.32}, \mathrm{~mm}$.

III Group $P_{A}=260 H / R^{0.15}, \mathrm{kN} / \mathrm{m}$;

$u_{A}=104 H / R^{0.38}, \mathrm{~mm}$.

Correlation-dispersion analysis of the optimization data has revealed a stable exponential relation between the parameters $P_{A}$ and $u_{A}$ with the index $H / R$, regardless of the coal-bearing massif structure. Therefore, the obtained scien- 
tific result can be formulated as follows: optimal parameters $P_{A}$ and $u_{A}$ of the fastening system deformation-strength characteristic in the reusable preparatory mine workings are in the exponential relation with the geomechanical index $H / R$, regardless of the coal-bearing massif structure group. This makes possible to implement a unified strategy for resourcesaving improvement of mine workings fastening systems for the entire Western Donbas region.

\section{Substantiating and calculating the rational deformation-strength characteristic of the fastening system}

The performed optimization of the fastening system operating modes gives us the condition $\left(P_{A}, u_{A}\right)$ of the equilibrium state of its interaction with the surrounding massif, which expresses only the final result in the form of the coordinates of $A$ point on the function $P(u)$ line of the support deformationstrength characteristic. Here it is supposed that the interaction process of the rock massif with support (fastening system) is developed over time and space, passing through many states with changing coordinates $P_{j}, u_{\mathrm{j}}$ from the period of the fastening system erection to the moment of the studied geomechanical process stabilization. In this term, it is important to ensure the mine working stability (by resource-saving methods) [29]-[33] throughout the entire period of the interaction development between the support and the rock massif; hence, the main task is in search for the optimal function $P(u)$ of the fastening system deformation-strength characteristic, for which two boundary values are known: $P=0, u=0$ and $P=P_{A}, u=u_{A}$. To substantiate the principle for searching the function $P(u)$, Figure 2 gives its schematic representation.

One of the main conditions for optimizing the interaction modes between the support and the rock massif is formulated as follows: support reaction $P$ should be not less than the load values $q_{1}$ and $q_{2}$ (Fig. 1) over the entire yielding property range from 0 to $u_{A}$.

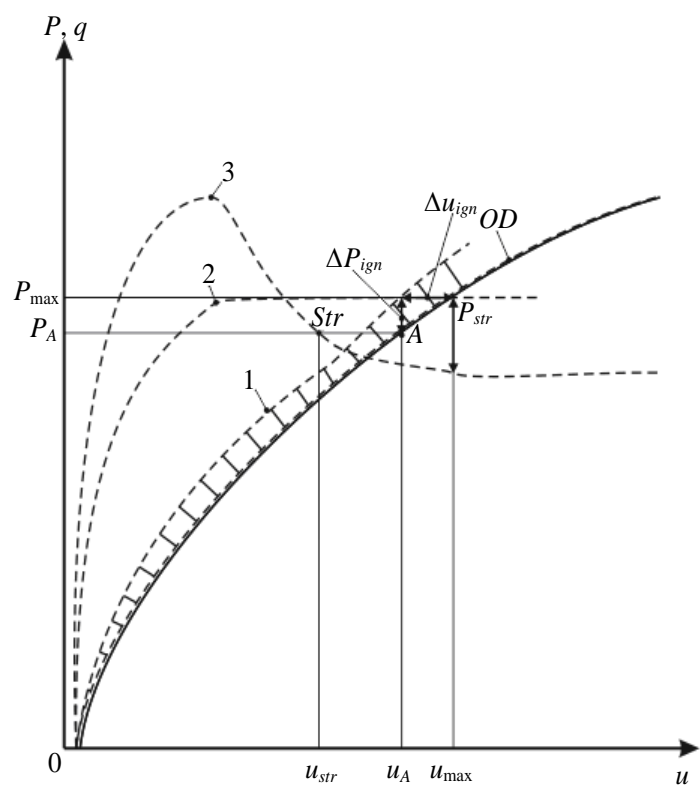

Figure 2. The scheme for calculating the rational deformationstrength characteristic of the fastening system: - deformation-strength characteristic of the rocks of the dome of natural equilibrium $q_{2}(u) ;---$ variants of fastening systems deformation-strength characteristic (lines “OD”, 1, 2 and 3)
The question is in choosing the load parameter $\left(q_{1}\right.$ and $\left.q_{2}\right)$ in each area of displacements $u_{j}$ development in the mine working rock contour.

When $u_{j}<u_{A}$, the function $q_{1}(u)$ always surpasses the function $q_{2}(u)$ and, at first glance, the deformation-strength characteristic of the weakened massif $q_{1}(u)$ is the main one when choosing the deformation-strength characteristic $P(u)$ of support. But, two factors are important here:

- firstly, in the range of $u_{j}<u_{A}$, a support retains a reserve of yield, which enables to "deviate" from excessive loads;

- secondly, the function $q_{1}(u)$ tends to decrease with increasing yielding property $u_{j}$ of support.

The mentioned factors make it possible to consider the function $q_{1}(u)$ as a secondary one: provided for the sufficient yielding property of support (not less than the value $u_{A}$ ), the load $q_{1}$ becomes less than the load $q_{2}$. Then the determining factor is the deformation-strength characteristic of the rocks of the dome of natural equilibrium $q_{2}(u)$ : under the condition:

$P u \geq q_{2} u$,

over the entire range $\left(0 \leq u \leq u_{A}\right)$ of the rock contour displacements development in mine working, its stability will be ensured.

Consider the most characteristic variants of the condition (10), shown in Figure 2. The optimum variant for the support deformation-strength characteristic $P(u)$ is the equality fulfilment according to the condition (10); therewith, the support reaction will be minimally sufficient (dashed line " $O D$ ") of all possible cases. But, such a variant is fraught with a state of limit stability of support and mine working, which can be disturbed by a number of reasons:

- different dynamic manifestations of the subsidence process in the mine working roof are taken into account by the dynamic factor $K_{d}$ in the formula (1), which is determined according to the normative document [28];

- an intensive action of factors weakening the rock is possible, in excess of the norm according to documents [28];

- any prediction based on modelling the geomechanical processes also has a certain accuracy;

- an action of other reasons is possible.

Therefore, it is advisable to specify a certain factor of ignorance $\left(K_{i g n}>1\right)$ to the optimal function $P(u)$, which compensates for the possible action of negative factors (line 1 in Figure 2):

- an increase in the required support reaction by a value of $\Delta P_{i g n}$ will increase the reliability of recommendations with an unpredictable increase in the rock pressure;

- an increase in the required yielding property by a value of $\Delta u_{\text {ign }}$ will ensure a "deviation" from excessive load in case of unpredictable increase in the rock contour displacements of mine working.

As it can be seen from the scheme, the parameters $\Delta P_{i g n}$ and $\Delta u_{i g n}$ are interconnected and depend on the value of the factor of ignorance $K_{i g n}$. For mining-engineering calculations, it is generally accepted to specify an accuracy within $15-20 \%$ to consider the influence of different insignificantly predicted factors. Therefore, in a first approximation, it can be accepted $K_{i g n}=1.15-1.20$, and the formula for calculating the rational deformation-strength characteristic of support takes the form:

$$
P u=K_{d} \cdot K_{i g n} B \gamma \frac{1-\alpha_{1}^{2} 1-K_{\text {inf }} / 100}{0.15+0.003 \alpha_{2}-0.18 \alpha_{1}} u \text {. }
$$


The function $P(u)$ reflecting the rational deformationstrength characteristic of support is illustrated by line 1 on the scheme of Figure 2. As can be seen, it is located slightly above the optimal line "OD", but an excess in the "margin" of the support stability factor is relatively small and is determined by the shaded area. The value of margin according to the support reaction is:

$$
\Delta P_{\text {ing }}=K_{\text {ing }}-1 P_{A},
$$

according to its yielding property:

$\Delta u_{\text {ing }}=K_{\text {ing }}-1 u_{A}$.

Here the optimal parameters $P_{A}$ and $u_{A}$ are calculated by the expressions (4)-(9).

Finally, the rational deformation-strength characteristic of support (fastening system) is determined by the formula (11), its load-bearing capacity $P_{\max }$ is calculated by the expression:

$P_{\max }=K_{\text {ing }} P_{A}$,

and maximum yielding property $u_{\max }$ - by the formula:

$u_{\max }=u_{A}$,

with account of equations (4)-(9).

There are other possible variants for selecting the rational deformation-strength characteristic of support, the function of which is not similar to the function $q_{2}(u)$. Thus, the line 2 in Figure 2 shows the well-known mode of constant resistance of support, which, not without reason, many experts consider the most effective. For example, the frame support from the special SCP profile [34] operates in the mode close to this one, but under condition of its highquality fastening: in the initial period of loading, the frame resists like a sufficiently rigid structure. And then there is a periodic activating of the yielding joists with a slight increase in the resistance reaction until the moment when the constructive yielding property value is exhausted; then, a rigid mode occurs with a sharp increase in the load onto support. If the support reaction in the constant resistance mode is equal to $P_{\max }$ (Fig. 2), then such its deformationstrength characteristic is assigned to the group of rational ones, provided that the constructive yielding property of support is not less than the value $u_{\max }$ for a given miningand-geological maintenance of mine working.

One more variant of the deformation-strength characteristic of support is shown by line 3 and is quite common [33]-[35] for various types of roof-bolting supports: in the initial period of resistance, the roof-bolts, as well as armoured and rock structures strengthened by them, have increased rigidity. And then (at a partial adhesion loss of the roof-bolt reinforcement with the rock walls of the bore hole) with an increase in the yielding property, the resistance of the roof bolts, as well as armoured and rock structures decreases. Such a deformation-strength characteristic cannot be considered satisfactory [36]-[39], since at a certain point of time ( $u=u_{s t r}$ ) the fastening structure reaction becomes less than the optimal value $P_{A}$ and it is required its prompt strengthening by the value of $P_{\text {str }}$ (Fig. 2).

It should be separately emphasized that in the formula (15) the factor of ignorance is absent for the reason, which can be explained using Figure 2. If to specify to the yielding property value $u_{\max }$ the same value of factor of ignorance as for the reaction $P_{\max }$, then the following situation arises:

- with increasing (dashed line 1 ) function $P(u)$, the additional margin of yielding property $\Delta u_{\text {ing }}$ causes an almost double margin in the value of the reaction $P_{\max }$, which is not expedient;

- with the function $P(u)=$ const (dashed line 2 ), which reflects the ideal mode of constant resistance, the margin of yielding property increases the load from the weight of rocks of the dome of natural equilibrium and, as it were, neutralizes the margin of $\Delta P_{i n g}$ by the value of the fastening structure reaction, which is also not a positive solution;

- with a decreasing function $P(u)$ (dashed line 3), the margin of yielding property leads to an increase in the missing reaction of the fastening structure compared to the rational value calculated by formula (14).

Summing up the performed studies, it should be noted that a very intelligible methodology has been created for calculating the deformation-strength characteristic of support (fastening system), depending on the mining and geological conditions for maintaining the mine working. As a rule, the fastening system of the reusable mine workings includes several fastening elements that are assembled in accordance with the calculated general deformation-strength characteristic.

\section{Conclusions}

The patterns have been determined of the geomechanical factors influence on the choice of optimal parameters of the fastening system deformation-strength characteristic: its minimum necessary reaction (load-bearing capacity) and the value of yielding property. The patterns have been obtained in the form of graphs and regression equations for calculating the fastening system optimal parameters. A stable exponential relation has been revealed between the fastening system optimal parameters and the geomechanical index of the mining conditions, regardless of the coal-bearing massif structure; this makes possible to implement a unified strategy for resource-saving improvement of mine working fastening systems for the entire Western Donbas region.

According to the determined optimal parameters of the fastening systems operating modes, a substantiation has been made and a methodology has been developed for calculating a function describing its rational deformation-strength characteristic depending on the mining and geological conditions for maintaining reusable preparatory mine workings. The methodology is intelligible and practical in terms of the necessary calculations of the fastening system rational parameters as a whole, for which the fastening components constituting it are selected.

\section{Acknowledgements}

The authors express their gratitude to the management of DTEK Coal Unit for their help in organizing the experimental research.

\section{References}

[1] Yu, S., Wu, A., Wang, Y., \& Li, T. (2017). Pre-reinforcement grout in fractured rock masses and numerical simulation for optimizing shrinkage stoping configuration. Journal of Central South University, 24(12), 29242931. https://doi.org/10.1007/s11771-017-3706-3

[2] Guan, K., Zhu, W.C., Niu, L.L., \& Wang, Q.Y. (2017). Three-dimensional upper bound limit analysis of supported cavity roof with arbitrary profile in Hoek-Brown rock mass. Tunnelling and Underground Space Technology, (69), 147-154. https://doi.org/10.1016/j.tust.2017.06.016 
[3] Santos, V., Da Silva, P.F., \& Brito, M.G. (2018). Estimating RMR values for underground excavations in a rock mass. Minerals, 8(3). https://doi.org/10.3390/min 8030078

[4] Chen, Q., Qin, S., \& Yin, T. (2019). Study on solution to the maximum movable region of the surrounding rock in fractured rock mass roadways. Journal of Mining and Safety Engineering, 36(2), 240-247. https://doi.org/10.13545/j.cnki.jmse.2019.02.004

[5] Li, G., Ma, F., Liu, G., Zhao, H., \& Guo, J. (2019). A strain-softening constitutive model of heterogeneous rock mass considering statistical damage and its application in numerical modeling of deep roadways. Sustainability, 11(8), 2-19. https://doi.org/10.3390/su11082399

[6] Bondarenko, V., Kovalevska, I., Symanovych, G., Sotskov, V., \& Barabash, M. (2018). Geomechanics of interference between the operation modes of mine working support elements at their loading. Mining Science, (25), 219-235. https://doi.org/10.5277/msc182515

[7] Toderas, M. (2014). Rock massif - support mechanical interaction models proposed for the geomechanical conditions from Petrila colliery, Romania. Multidisciplinary Scientific GeoConference Surveying Geology and Mining Ecology Management, SGEM, 3(1) 521-528.

[8] Janas, P., Janas, K., Koubova, L., \& Krejsa, M. (2017). Modelling of closed steel supports for underground and mining works. Key Engineering Materials, (754), 313-316 https://doi.org/10.4028/www.scientific.net/KEM.754.313

[9] Symanovych, G., Demydov, M., \& Chervatuk, V. (2013). Influence mechanism of rock mass structure forming a stress on a face support. Annual Scientific-Technical Collection - Mining of Mineral Deposits 2013, 77-81. https://doi.org/10.1201/b16354-14

[10] Lu, Y., Liu, C., Zhou, J., \& Chen, X. (2017). Failure structure characteristics of strata with upper thin and lower thick strata in ultra-close coal seams with simultaneous mining and relationship between shield and surrounding rock. Caikuang Yu Anquan Gongcheng Xuebao/Journal of Mining and Safety Engineering, 34(5), 832-837 and 860. https://doi.org/doi:10.13545/j.cnki.jmse.2017.05.002

[11] Xie, S., Pan, H., Zeng, J., Wang, E., Chen, D., Zhang, T., \& Qiao, S. (2019). A case study on control technology of surrounding rock of a large section chamber under a 1200-m deep goaf in Xingdong coal mine, China. Engineering Failure Analysis, (104), 112-125. https://doi.org/doi:10.1016/j.engfailanal.2019.05.039

[12] Kovalevska, I., Pilecki, Z., Husiev, O., \& Snihur, V. (2019). Assessment of the mutual influence of deformation-strength characteristics of the fastening system elements. E3S Web of Conferences, (123), 01006. https://doi.org/10.1051/e3sconf/201912301006

[13] Bondarenko, V., Symanovych, H., Kicki, J., Barabash, M., \& Salieiev, I. (2019). The influence of rigidity of the collapsed roof rocks in the minedout space on the state of the preparatory mine workings. Mining of Mineral Deposits, 13(2), 27-33. https://doi.org/10.33271/mining13.02.027

[14] Kovalevska, I., Zhuravkov, M., Chervatiuk, V., Husiev, O., \& Snihur, V. (2019). Generalization of trends in the influence of geomechanics factors on the choice of operation modes for the fastening system in the preparatory mine workings. Mining of Mineral Deposits, 13(3), 1-11. https://doi.org/10.33271/mining 13.03.001

[15] Prusek, S., Rajwa, S., Wrana, A., \& Krzemień, A. (2017). Assessment of roof fall risk in longwall coal mines. International Journal of Mining, Reclamation and Environment, 31(8), 558-574. https://doi.org/10.1080/17480930.2016.1200897

[16] Kovalevs'ka, I., Symanovych, G., \& Fomychov, V. (2013). Research of stress-strain state of cracked coal-containing massif near-the-working area using finite elements technique. Annual Scientific-Technical Collection - Mining of Mineral Deposits 2013, 159-163. http://dx.doi.org/10.1201/b16354-28

[17] Bondarenko, V., Kovalevs'ka, I., \& Ganushevych, K. (2014). Progressive technologies of coal, coalbed methane, and ores mining. London, United Kingdom: CRC Press, Taylor \& Francis Group. https://doi.org/10.1201/b17547

[18] Pivnyak, G.G., \& Shashenko, O.M. (2015). Innovations and safety for coal mines in Ukraine. Naukovyi Visnyk Natsionalnoho Hirnychoho Universytetu, (6), 118-121.

[19] Piwniak, G.G., Bondarenko, V.I., Salli, V.I., Pavlenko, I.I., \& Dychkovskiy, R.O. (2007). Limits to economic viability of extraction of thin coal seams in Ukraine. Technical, Technological and Economic Aspects of Thin-Seams Coal Mining International Mining Forum 2007, 129-132. https://doi.org/10.1201/noe0415436700.ch16

[20] Naduty, V., Malanchuk, Z., Malanchuk, Y., \& Korniyenko, V. (2016). Research results proving the dependence of the copper concentrate amount recovered from basalt raw material on the electric separator field intensity. Eastern-European Journal of Enterprise Technologies, 5(5(83)), 19-24. https://doi.org/10.15587/1729-4061.2016.79524

[21] Stupnik, M., Kolosov, V., Kalinichenko, V., \& Pismennyi, S. (2014). Physical modeling of waste inclusions stability during mining of complex structured deposits. Progressive Technologies of Coal, Coalbed Methane, and Ores Mining, 25-30. https://doi.org/10.1201/b17547

[22] Naduty, V., Malanchuk, Z., Malanchuk, E., \& Korniyenko, V. (2015). Modeling of vibro screening at fine classification of metallic basalt. New Developments in Mining Engineering 2015: Theoretical and Practical Solutions of Mineral Resources Mining, 441-443. https://doi.org/10.1201/b19901-77

[23] Bondarenko, V., Symanovych, G., \& Koval, O. (2012). The mechanism of over-coal thin-layered massif deformation of weak rocks in a longwall. Geomechanical Processes During Underground Mining Proceedings of the School of Underground Mining, 41-44. https://doi.org/10.1201/b13157-8

[24] Skipochka, S., Krukovskyi, O., Serhiienko, V., \& Krasovskyi, I. (2019). Physical modeling of the rock bolt interaction with the rock massif. E3S Web of Conferences, (123), 01002 https://doi.org/10.1051/e3sconf/201912301002

[25] Sadovenko, I., \& Tymoshchuk, V. (2014). Hydrogeomechanical processes of occurrence in disturbed rock mass by mine workings. Progressive Technologies of Coal, Coalbed Methane, and Ores Mining, 47-51. https://doi.org/10.1201/b17547-10

[26] Inkin, O., Tishkov, V., Dereviahina, N., \& Sotskov, V. (2018). Integrated analysis of geofiltrational parameters in the context of underground coal gasification relying upon calculations and modeling. E3S Web of Conferences, (60), 00035. https://doi.org/10.1051/e3sconf/20186000035

[27] Timoshuk, V., Tishkov, V., Inkin, O., \& Sherstiuk, E. (2012). Influence of coal layers gasification on bearing rocks. Geomechanical Processes During Underground Mining - Proceedings of the School of Underground Mining, 109-113. https://doi.org/10.1201/b13157-19

[28] SOU 10.1.00185790.011:2007. (2007). Pidhotovchi vyrobky na polohykh plastakh. Vybir kriplennia, sposobiv i zasobiv okhorony. Standart Minvuhlepromu Ukrainy. Donetsk: Donetskyi vuhilnyi instytut.

[29] Bock, S., \& Prusek, S. (2015) Numerical study of pressure on dams in a backfilled mining shaft based on PFC3D code. Computers and Geotechnics, (66), 230-244. https://doi.org/10.1016/j.compgeo.2015.02.005

[30] Majcherczyk, T., Niedbalski, Z., Malkowski, P., \& Bednarek, L. (2014). Analysis of yielding steel arch support with rock bolts in mine roadways stability aspect. Archives of Mining Sciences, 59(3), 641-654. https://doi.org/10.2478/amsc-2014-0045

[31] Bondarenko, V.I., Simanovich, G.A., Kovalevska, I.A., Fomichov, V.V., \& Serdiuk, V.P. (2007). Research of rock stresses and deformations around mining workings. Technical, Technological and Economic Aspects of Thin-Seams Coal Mining International Mining Forum 2007, 47-56. https://doi.org/10.1201/noe0415436700.ch6

[32] Sdvizhkova, Ye.A., Babets, D.V., \& Smirnov, A.V. (2014). Support loading of assembly chamber in terms of Western Donbas plough longwall. Naukovyi Visnyk Natsionalnoho Hirnychoho Universytetu, (5). 26-32.

[33] Babets, D.V., Sdvyzhkova, O.O., Larionov, M.H., \& Tereshchuk, R.M (2017). Estimation of rock mass stability based on probability approach and rating systems. Naukovyi Visnyk Natsionalnoho Hirnychoho Universytetu, (2), 58-64.

[34] Kovalevska, I., Barabash, M., Husiev, O., \& Snihur, V. (2018). Interaction of deformation-strength characteristics of the support load-bearing elements in the preparatory workings. E3S Web of Conferences, (60), 00002. https://doi.org/10.1051/e3sconf/20186000002

[35] Małkowski, P., \& Ostrowski, Ł. (2019). Convergence monitoring as a basis for numerical analysis of changes of rock-mass quality and Hoek-Brown failure criterion parameters due to longwall excavation. Archives Mining Sciences, 64(1), 93-118. https://doi.org/10.24425/ams.2019.126274

[36] Lozynskyi, V., Saik, P., Petlovanyi, M., Sai, K., \& Malanchyk, Z. (2018). Analytical research of the stress-deformed state in the rock massif around faulting. International Journal of Engineering Research in Africa, (35), 77-88. https://doi.org/10.4028/www.scientific.net/JERA.35.77

[37] Malanchuk, Z.R., Moshynskyi, V.S., Korniienko, V.Ya., Malanchuk, Ye.Z., \& Lozynskyi, V.H. (2019). Substantiating parameters of zeolitesmectite puff-stone washout and migration within an extraction chamber. Naukovyi Visnyk Natsionalnoho Hirnychoho Universytetu, (6), 11-18. https://doi.org/10.29202/nvngu/2019-6/2

[38] Bondarenko, V., Kovalevs'ka, I., Svystun, R., \& Cherednichenko, Y. (2013). Optimal parameters of wall bolts computation in the united bearing system of extraction workings frame-bolt support. Annual ScientificTechnical Collection - Mining of Mineral Deposits 2013, 5-9. https://doi.org/10.1201/b16354-3

[39] Bondarenko, V.I., Kharin, Ye.N., Antoshchenko, N.I., \& Gasyuk, R.L. (2013). Basic scientific positions of forecast of the dynamics of methane release when mining the gas bearing coal seams. Naukovyi Visnyk Natsionalnoho Hirnychoho Universytetu, (5), 24-30. 
Встановлення закономірностей впливу геомеханічних факторів на навантаження кріпильної системи підготовчих виробок

В. Бондаренко, Г. Симанович, М. Барабаш, О. Гусєв, І. Салєєв

Мета. Обгрунтування розрахунку раціональних параметрів реакції і податливості кріпильної системи підготовчих виробок.

Методика. Аналіз напружено-деформованого стану системи “масив - кріплення" і нормативної документації з розрахунку кріплення підготовчих виробок для визначення закономірностей зв'язку параметрів кріплення системи з основними геомеханічними факторами.

Результати. Визначено закономірності впливу геомеханічних факторів на параметри реакції і податливості кріплення системи й отримано аналітичні вирази для їх розрахунку.

Наукова новизна. Кореляційно-дисперсійний аналіз даних оптимізації показав стабільний степеневий зв'язок параметрів реакції і податливості кріплення з показником $H / R$ незалежно від структури вуглевмісного масиву.

Практична значимість. Розроблено розрахунок деформаційно-силової характеристики кріпильної системи залежно від гірничо-геологічних умов підтримки підготовчої виробки.

Ключові слова: підготовча виробка, кріплення, реакиія і податливість кріплення, характеристика, оптимізація, розрахунок

Установление закономерностей влияния геомеханических факторов на нагружение крепежной системы подготовительных выработок

В. Бондаренко, Г. Симанович, М. Барабаш, А. Гусев, И. Салеев

Цель. Обоснование расчета рациональных параметров реакции и податливости крепежной системы подготовительных выработок.

Методика. Анализ напряженно-деформированного состояния системы “массив - крепь” и нормативной документации по расчету крепи подготовительных выработок для определения закономерностей связи параметров крепежной системы с основными геомеханическими факторами.

Результаты. Определены закономерности влияния геомеханических факторов на параметры реакции и податливости крепежной системы и получены аналитические выражения для их расчета.

Научная новизна. Корреляционно-дисперсионный анализ данных оптимизации показал стабильную степенную связь параметров реакции и податливости крепи с показателем $H / R$ вне зависимости от структуры углевмещающего массива.

Практическая значимость. Разработан расчет деформационно-силовой характеристики крепежной системы в зависимости от горно-геологических условий поддержания подготовительной выработки.

Ключевые слова: подготовительная выработка, крепь, реакиия и податливость крепи, характеристика, оптимизация, расчет

\section{Article info}

Received: 14 August 2019

Accepted: 23 January 2020

Available online: 3 February 2020 